\title{
Effect of Fertilization on Growth of Eucalyptus urophylla Plantation
}

\author{
Tran Van $\mathrm{Do}^{1,2^{*}}$, Dang Van Thuyet ${ }^{2}$ and Nguyen Toan Thang ${ }^{2}$ \\ ${ }^{1}$ Research Institute for Sustainable Humanosphere, Kyoto University, Uji, Kyoto, Japan. \\ ${ }^{2}$ Silviculture Research Institute, Vietnamese Academy of Forest Sciences, Hanoi, Vietnam.
}

This work was carried out in collaboration between all authors. Authors TVD and DVT designed the study, wrote the protocol and interpreted the data. Authors DVT and NTT anchored the field study, gathered the data and performed preliminary data analysis. Author TVD managed the literature searches and produced the initial draft. All authors read and approved the final manuscript.

Article Information

DOI: $10.9734 / J A L S I / 2017 / 34069$

Editor(s):

(1) J. Rodolfo Rendón Villalobos, Department of Technological Development, National Polytechnic Institute, México.

Reviewers:

(1) Nazimah Maqbool, University of Sargodha, Faisalabad, Pakistan. (2) Moses Ahmed Daramy, Sierra Leone Agricultural Research Institute, Sierra Leone. (3) M. Yuvaraj, Tamil Nadu Agricultural University, India. Complete Peer review History: http://www.sciencedomain.org/review-history/19255

Original Research Article

Received $12^{\text {th }}$ May 2017

Accepted 26 ${ }^{\text {th }}$ May 2017

Published $30^{\text {th }}$ May 2017

\begin{abstract}
Fertilization has been widely applied to increase and sustain productivity of plantations, especially in poor soils. N, P, K, and compost are usually used for forest plantation in Vietnam. The amount of fertilizer and rates of concerned nutrient are decided basing on species and edaphic condition. In this study, four fertilizer applications were used at planting; $100 \mathrm{~g} \mathrm{NPK}+200 \mathrm{~g}$ compost, $150 \mathrm{~g}$ $\mathrm{NPK}+150 \mathrm{~g}$ compost, $200 \mathrm{~g}$ NPK $+100 \mathrm{~g}$ compost, and control (no fertilization) for Eucalyptus urophylla plantation grown in North Central and Southern, Vietnam with planting density of 1,330 trees ha $^{-1}$ (spacing $2.5 \times 3 \mathrm{~m}$ ). Growth data were collected after planting three years. Fertilizer applications had significant effects on diameter at breast height (DBH), crown diameter $\left(D_{c}\right)$, and dry biomass of 3-year-old plantations in both sites. A 3-year-old. E. urophylla plantation had largest DBH $(9.7 \mathrm{~cm})$ and dry biomass $\left(67.2 \mathrm{Mg} \mathrm{ha}^{-1}\right)$ in fertilizer application of $200 \mathrm{~g} \mathrm{NPK}+100$ $\mathrm{g}$ compost in Southern site, and smallest DBH $(6.4 \mathrm{~cm})$ and dry biomass $\left(38.2 \mathrm{Mg} \mathrm{ha}^{-1}\right)$ in control also in Southern site. Comparing between two sites at three treatments with fertilizer indicated the significant higher dry biomass in Southern site than that in North Central site. While, it was
\end{abstract}

*Corresponding author: E-mail: dotranvan@hotmail.com,tran_dovan@rish.kyoto-u.ac.jp; 
converted in control, indicating higher dry biomass in North Central site. To grow E. urophylla, 200 g NPK+100 g compost should be applied at planting for Southern site. While, $100 \mathrm{~g} \mathrm{NPK}+200 \mathrm{~g}$ compost is encouraged for North Central site.

Keywords: Edaphoclimatic condition; fertilizer requirement; soil nutrient; sustainable production.

\section{INTRODUCTION}

Plantations of exotic trees are assuming an increasingly significant role in landscape management and the rural economy in many tropical regions [1]. Of which, Eucalyptus, fast growing tree species, could meet the growing demands of pulp wood and timber.

The soils intended for forest plantations usually have low fertility, which require fertilization to maintain high yields. $\mathrm{N}, \mathrm{P}$, and $\mathrm{K}$ are major nutrients applied to plantation [2,3]. Fertilization in eucalypt plantations provides production gains, ranging from $5 \%$ to over $90 \%$ of wood production; depending on nutrient, stand age, and edaphoclimatic conditions of the site [4,5]. Stand growth may be greater in higher quality sites or may be accelerated by fertilizer application. Studies on eucalypt plantation have shown that absolute and relative responses of potential sawlog trees often increase with fertilizer application [6-8]. Similar to eucalyptus stands, fertilizer application has increased growths of other tree species such as Pinus contorta [9] and Pinus sylvestris stands [10].

The development of silvicultural practices and eucalypt breeding increased yields and reduced rotation time, which required high nutrient output to sites and raised the responses for $\mathrm{N}, \mathrm{P}$, and $\mathrm{K}$ fertilization [11]. To meet $\mathrm{N}, \mathrm{P}$, and $\mathrm{K}$ nutritional demands for different site conditions, different fertilizers and different amount are necessary to reach the maximum yield $[12,13]$. For optimum growth and development, planted trees requires large amount of nutrient [14]. N, P, and K play an important role for better growth and development in plants [15,16], especially when trees are planted in poor soil. Knowledge on nutrient relations in eucalypt plantations is therefore imperative for fertilizer application to maintain nutrient contents within limits that ensure the production sustainability.

In Vietnam, eucalypt plantation is becoming increasingly important in contributing to livelihood of million people in rural areas. It is imperative that fertilization is important to increase and sustain productivity for eucalypt plantations. The objective of this study was to examine the effects of fertilization on growth and dry biomass of eucalypt plantations in Vietnam.

\section{MATERIALS AND METHODS}

\subsection{Study Site}

This study was conducted in North Central and Southern, Vietnam. The Southern site has mean annual temperature of $25-27^{\circ} \mathrm{C}$, annual precipitation of $1,400-2,500 \mathrm{~mm}$, and annual humidity of $84 \%$. Soil has average $\mathrm{pH}$ of $4.0-4.5$, high organic matter, and nutrient content. The North Central site has mean annual temperature of $22-23^{\circ} \mathrm{C}$, annual precipitation of $2,300-2,400$ $\mathrm{mm}$, and annual humidity of $85-90 \%$. Soil has average $\mathrm{pH}$ of $4.1-4.3$, high organic matter, and nutrient content [17].

\subsection{Plantation Establishment}

This study was conducted for $E$. urophylla, grown in North Central and Southern, Vietnam.

The experiment included four treatments; (a) $100 \mathrm{~g} \mathrm{NPK}+200 \mathrm{~g}$ compost/tree, (b) $150 \mathrm{~g}$ $\mathrm{NPK}+150 \mathrm{~g}$ compost/tree, (c) $200 \mathrm{~g} \mathrm{NPK}+100 \mathrm{~g}$ compost/tree, and (d) control (no fertilization application). In all fertilization treatments, planting density of 1,330 trees ha-1 (spacing $2.5 \times 3 \mathrm{~m}$ ) was used. Fertilization was applied at planting manually. Planting holes were prepared manually with the size of $30 \times 30 \times 30 \mathrm{~cm}$. Fertilization was put in the hole, then well mixed with fine soil before growing seedlings of 30-35 $\mathrm{cm}$ tall. Seedlings were planted during rainy season. After planting, no further silvicultural techniques were applied.

Experiment was conducted in a randomized complete block with three replicates. Each replicate was conducted in a plot of $20 \times 20 \mathrm{~m}$, which included 36 trees. Totally, there were two blocks for two sites. Each block contained 12 plots (4 treatments $\times 3$ replicates).

\subsection{Data Collection and Analysis}

Data included diameter at breast height (DBH in $\mathrm{cm})$, stem height $(\mathrm{H}$ in $\mathrm{m})$, and crown diameter (Dc in $\mathrm{m}$ ) were measured after planting three years. All surviving stems in plots were measured. 
Dry biomass of each stem ( $B$ in $\mathrm{kg}$; including leaves, branches, stems, roots) was estimated following Eq. 1 [18]:

$$
\mathrm{B}=2.7262^{\star} \mathrm{DBH}^{1.3016}
$$

Survival rate, mean $\mathrm{DBH}$, mean $\mathrm{H}$, and mean $\mathrm{Dc}$ were calculated for each treatment in each site separately. Dry biomass was estimated for plot mean then transferred to unit of $\mathrm{Mg} \mathrm{ha}^{-1}$.

Comparison among treatments in each site was conducted with ANOVA one-factor and post-hoc test. While, comparing between two sites for each fertilization treatment separately was conducted by pair-comparison. Statistical analysis was conducted using SAS 9.2.

\section{RESULTS}

There was no significant difference of survival rate of a 3-year-old E. urophylla plantation in North Central among four fertilizer treatments (Table 1). The survival rates was ranging from $94.7 \%$ to $96 \%$.

The deference of means of $\mathrm{DBH}$, stem height, and Dc was statistically significant. The tallest mean stem height $(8.9 \mathrm{~m})$ was found in fertilizer application of $150 \mathrm{~g} \mathrm{NPK}+150 \mathrm{~g}$ compost, and the shortest mean stem height $(7.4 \mathrm{~m})$ belonged to control. Meanwhile, the largest mean DBH (7.9 $\mathrm{cm})$ and $\mathrm{Dc}(2.3 \mathrm{~m})$ were found in fertilizer application of $100 \mathrm{~g} \mathrm{NPK}+200 \mathrm{~g}$ compost, and the smallest mean DBH $(7.4 \mathrm{~cm})$ and Dc $(1.7 \mathrm{~m})$ were found in control (Table 1).
The significant difference of DBH led to significant difference of dry biomass of a3-yearold E. urophylla plantation in North Central among fertilizer applications (Table 1). The highest dry biomass of $50.7 \mathrm{Mg} \mathrm{ha}^{-1}$ belonged to fertilizer application of $100 \mathrm{~g} N \mathrm{NP}+200 \mathrm{~g}$ compost, reducing to $48.8 \mathrm{Mg} \mathrm{ha}^{-1}$ in fertilizer application of $200 \mathrm{~g} \mathrm{NPK}+100 \mathrm{~g}$ compost, to 47.3 $\mathrm{Mg} \mathrm{ha}^{-1}$ in fertilizer application of $150 \mathrm{~g} \mathrm{NPK}+150$ $\mathrm{g}$ compost, and to $46.6 \mathrm{Mg} \mathrm{ha}^{-1}$ in control (Table 2).

There was no significant difference of survival rate of a 3-year-old E. urophylla plantation in Southern among four fertilizer applications (Table 2). The survival rates was ranging from lowest $94 \%$ in control to highest $96.3 \%$ in fertilizer application of $200 \mathrm{~g}$ NPK $+100 \mathrm{~g}$ compost.

The deference of mean Dc was not significant, ranging from $1.1 \mathrm{~m}$ in control to $1.3 \mathrm{~m}$ in both fertilizer applications of $100 \mathrm{~g}$ NPK $+200 \mathrm{~g}$ compost and $150 \mathrm{~g}$ NPK $+150 \mathrm{~g}$ compost. Meanwhile, the deference of means of $\mathrm{DBH}$ and stem height was statistically significant. The tallest mean stem height $(8.2 \mathrm{~m})$ was found in fertilizer application of $100 \mathrm{~g}$ NPK $+200 \mathrm{~g}$ compost, and the shortest mean stem height (6.4 $\mathrm{m})$ belonged to control. The largest mean DBH $(9.7 \mathrm{~cm})$ and $\mathrm{Dc}(2.3 \mathrm{~m})$ were found in fertilizer application of $200 \mathrm{~g} \mathrm{NPK}+100 \mathrm{~g}$ compost, and the smallest mean DBH $(6.4 \mathrm{~cm})$ was found in control (Table 2).

Table 1. Effects of fertilizer application on survival rate, growth, and dry biomass of a 3-yearold Eucalyptus urophylla plantation in North Central, Vietnam (means \pm SD)

\begin{tabular}{|c|c|c|c|c|c|}
\hline Fertilizer application & $\begin{array}{l}\text { Survival } \\
\text { rate (\%) }\end{array}$ & $\begin{array}{l}\text { DBH } \\
\text { (cm) }\end{array}$ & $\begin{array}{c}\mathrm{H} \\
(\mathrm{m})\end{array}$ & $D_{c}(m)$ & $\begin{array}{l}\text { Dry biomass } \\
\left(\mathrm{Mg} \mathrm{ha}^{-1}\right)\end{array}$ \\
\hline $100 \mathrm{~g} \mathrm{NPK}+200 \mathrm{~g}$ compost & $95.0 \pm 1.57$ & $7.9 \pm 0.75^{\mathrm{a}}$ & $8.4 \pm 1.12^{\mathrm{a}}$ & $2.3 \pm 0.21^{a}$ & $50.7 \pm 2.8^{\mathrm{a}}$ \\
\hline $150 \mathrm{~g}$ NPK $+150 \mathrm{~g}$ compost & $94.7 \pm 2.15$ & $7.5 \pm 0.68^{b}$ & $8.9 \pm 0.91^{a}$ & $1.7 \pm 0.19^{b}$ & $47.3 \pm 2.8^{\mathrm{b}}$ \\
\hline $200 \mathrm{~g} \mathrm{NPK}+100 \mathrm{~g}$ compost & $96.0 \pm 1.32$ & $7.6 \pm 0.67^{\mathrm{b}}$ & $7.9 \pm 1.01^{\mathrm{b}}$ & $1.8 \pm 0.19^{b}$ & $48.8 \pm 2.4^{\mathrm{b}}$ \\
\hline Control & $95.0 \pm 2.23$ & $7.4 \pm 0.65^{\mathrm{b}}$ & $7.4 \pm 0.89^{\mathrm{b}}$ & $1.7 \pm 0.15^{\mathrm{b}}$ & $46.6 \pm 2.1^{\mathrm{b}}$ \\
\hline
\end{tabular}

Table 2. Effects of fertilizer application on survival rate, growth, and dry biomass of a 3-yearold Eucalyptus urophylla plantation in Southern, Vietnam (means \pm SD)

\begin{tabular}{|c|c|c|c|c|c|}
\hline Fertilizer application & $\begin{array}{l}\text { Survival } \\
\text { rate (\%) }\end{array}$ & $\begin{array}{l}\text { DBH } \\
\text { (cm) }\end{array}$ & $\begin{array}{l}\mathbf{H} \\
(\mathrm{m})\end{array}$ & $\begin{array}{l}D_{c} \\
(m)\end{array}$ & $\begin{array}{l}\text { Dry biomass } \\
\left(\mathrm{Mg} \mathrm{ha}^{-1}\right)\end{array}$ \\
\hline 100 & $95.3 \pm 2.15$ & $8.6 \pm 0.81^{a}$ & $8.2 \pm 1.11^{a}$ & $1.3 \pm 0.19$ & $56.9 \pm 3.4^{\mathrm{a}}$ \\
\hline $150 \mathrm{~g} \mathrm{NPK}+150 \mathrm{~g}$ & $95.0 \pm 2.21$ & $8.3 \pm 0.79^{\mathrm{a}}$ & $7.2 \pm 1.02^{b}$ & $1.3 \pm 0.18$ & $54.1 \pm 2.7^{\mathrm{a}}$ \\
\hline $200 \mathrm{~g}$ NPK $+100 \mathrm{~g}$ compost & $96.3 \pm 1.95$ & $9.7 \pm 0.89^{b}$ & $8.1 \pm 1.09^{a}$ & $1.4 \pm 0.17$ & $67.2 \pm 3.7^{b}$ \\
\hline Control & $94.0 \pm 2.35$ & $6.4 \pm 0.65^{\mathrm{c}}$ & $6.4 \pm 0.89^{c}$ & $1.1 \pm 0.19$ & $38.2 \pm 1.7^{\mathrm{c}}$ \\
\hline
\end{tabular}


Dry biomass was significant different among four fertilizer applications, as a result of significant difference of mean DBH (Table 2). The highest dry biomass of $67.2 \mathrm{Mg} \mathrm{ha}^{-1}$ belonged to fertilizer application of $200 \mathrm{~g}$ NPK $+100 \mathrm{~g}$ compost, reducing to $56.9 \mathrm{Mg} \mathrm{ha}^{-1}$ in fertilizer application of $100 \mathrm{~g} \mathrm{NPK}+200 \mathrm{~g}$ compost, to $54.1 \mathrm{Mg} \mathrm{ha}^{-1}$ in fertilizer application of $150 \mathrm{~g}$ NPK $+150 \mathrm{~g}$ compost, and to $38.2 \mathrm{Mg} \mathrm{ha}^{-1}$ in control (Table 2).

Comparing dry biomass of a 3-year-old E. urophylla plantation between North Central and Southern indicated that at all fertilizer applications the dry biomass was statistically significant different (Fig. 1). Of which, in fertilizer applications of $100 \mathrm{~g} \mathrm{NPK}+200 \mathrm{~g}$ compost, $150 \mathrm{~g}$ $\mathrm{NPK}+150 \mathrm{~g}$ compost, and $200 \mathrm{~g} \mathrm{NPK}+100 \mathrm{~g}$ compost dry biomass in Southern was significant higher than that in North Central. While, in control it was converted; dry biomass in North Central was significant higher than that in Southern. The comparison was $138 \%$ in fertilizer application of $200 \mathrm{~g} \mathrm{NPK}+100 \mathrm{~g}$ compost, $122 \%$ in control, $112 \%$ in fertilizer application of $100 \mathrm{~g}$ $\mathrm{NPK}+200 \mathrm{~g}$ compost, and $109 \%$ in fertilizer application of $150 \mathrm{~g} \mathrm{NPK}+150 \mathrm{~g}$ compost.

\section{DISCUSSION}

The response of fertilizer applications to plantation depends on degree of mismatch between nutrient supply and nutrient demand $[2,19]$. Nutrient did not affect on survival rate at both sites, as bagged-seedlings were used and planted in rainy season with enough water supply for initial growth which promotes enlargement of root system both vertically and horizontally before dry season coming [17]. In both sites, control treatment (no fertilizer application) had lowest growth of $\mathrm{DBH}$ and $\mathrm{H}$, resulting in lowest dry biomass (Tables 1 and 2). This indicated the significant importance of fertilizer applications in forest plantation, which were mentioned in other researches $[7,8,12,13]$.

In North Central site, compost fertilizer had better effects on growth and dry biomass of a 3-yearold E. urophylla plantation than NPK as highest mean $\mathrm{DBH}$ and dry biomass were found in fertilizer application of $100 \mathrm{~g}$ NPK $+200 \mathrm{~g}$ compost, highest amount of compost fertilizer (Table 1). While, it was converted in Southern site as largest mean DBH and dry biomass were found in fertilizer application of $200 \mathrm{~g} \mathrm{NPK}+100 \mathrm{~g}$ compost, highest amount of NPK. This may be explained by the difference of annual precipitation, which was higher in North Central site, leading to higher NPK loss by leaching and soil erosion [17].

The loss or infectiveness of fertilizer application, and other unknown reasons led to difference of dry biomass between two sites.

Crown diameter represents Leaf Area Index (LAI) of plantations. At the same planting density of 1,330 trees ha $^{-1}$, Dc of a 3-year-old E. urophylla plantation in North Central site was larger than

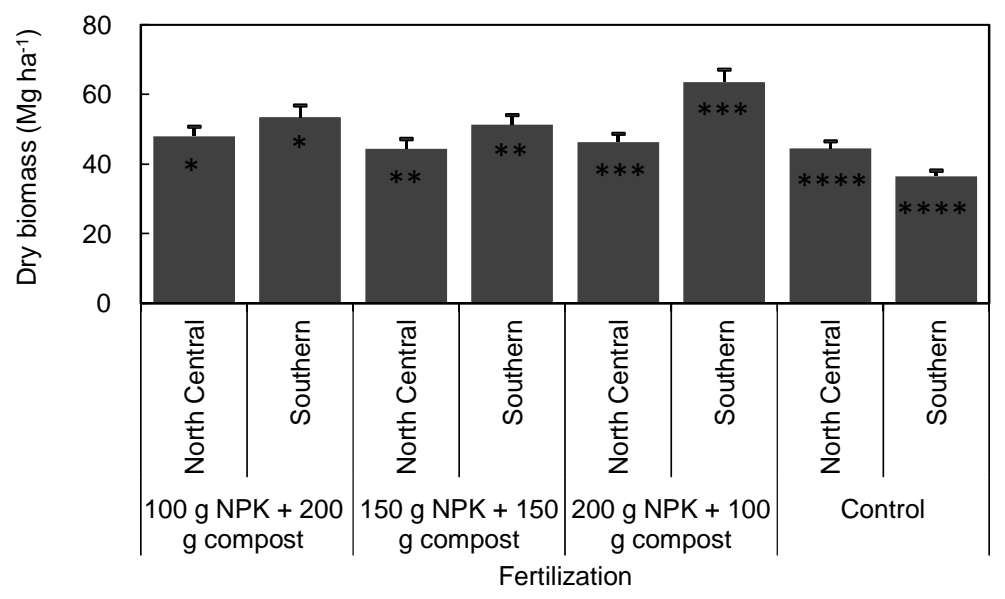

Fig. 1. Comparison of dry biomass of a 3-year-old plantation of Eucalyptus urophylla between North Central and Southern, Vietnam with different fertilizer applications

Vertical bars indicated $\pm S D$. Asterisks indicated the significant difference of dry biomass in corresponding fertilizer application at $p=0.05$ 
that in Southern site (Tables 1, 2), leading to higher LAI in North Central site. Higher LAI plantation has higher photosynthesis, which may lead to higher primary production [2,20,21]. However, dry biomass in Southern site, which had lower mean Dc, was higher than that in North Central site at all fertilizer applications. This may be explained by higher autotrophic respiration at higher mean $\mathrm{Dc} / \mathrm{LAl}$ of plantation in North Central site, leading to lower dry biomass.

The difference of growth and dry biomass between two sites may also result from difference of climate regime [4,5]. There are two distinct seasons in North Central site as summer/rainy season and winter/dry season (November-March), when planted trees may grow slower, leading to lower total production. While, in Southern site there is no winter season and rainfall distributes through the year, therefore planted trees grow equally whole year.

\section{CONCLUSIONS}

Fertilizer application had significant effects on growth and dry biomass of Eucalyptus urophylla plantation in both Southern and North Central, Vietnam. In both sites, control treatment (no fertilizer application) had lowest dry biomass as $46.6 \mathrm{Mg} \mathrm{ha}^{-1}$ in North Central site and 38.2 $\mathrm{Mg} \mathrm{ha}^{-1}$ in Southern site. While, the highest dry biomass in Southern site was $67.2 \mathrm{Mg} \mathrm{ha}^{-1}$ in fertilizer application of $200 \mathrm{~g}$ NPK $+100 \mathrm{~g}$ compost and it was $50.7 \mathrm{Mg} \mathrm{ha}^{-1}$ in North Central site in fertilizer application of $100 \mathrm{~g} \mathrm{NPK}+200 \mathrm{~g}$ compost. Compost fertilizer is better to apply for North Central site. While, NPK is better for Southern site.

\section{ACKNOWLEDGEMENTS}

This research is funded by Vietnam National Foundation for Science and Technology Development (NAFOSTED) under grant number 106-NN.06-2016.10. We would like to thank anonymous reviewers for constructive comments on the manuscript.

\section{COMPETING INTERESTS}

Authors have declared that no competing interests exist.

\section{REFERENCES}

1. FAO. Forest resources assessment 1990: Tropical countries. FAO Forestry Paper 112. Food and Agriculture Organization of the United Nations, Rome. 1993;59.
2. Smethurst P, Baillie C, Cherry M, Holz G. Fertilizer effects on LAI and growth of four Eucalyptus nitens plantations. For. Ecol. Manage. 2003;176:531-542.

3. Smethurst P, Holz G, Moroni M, Baillie C. Nitrogen management in Eucalyptus nitens plantations. For. Ecol. Manage. 2004;193: 63-80.

4. Pulito AP, de Moraes Goncalves JL, Smethurst PJ, Arthur Junior JC, Alvares CA, Tertulino Rocha JH, Huebner A, de Moraes LF, Miranda AC, Kamogawa MY, et al. Available nitrogen and responses to nitrogen fertilizer in Brazilian eucalypt plantations on soils of contrasting texture. Forests. 2015;6:973-991.

5. Almeida JCR, Laclau JP, Goncalves JLD, Ranger J, Saint-Andre L. A positive growth response to $\mathrm{NaCl}$ applications in Eucalyptus plantations established on $\mathrm{K}$ deficient soils. For. Ecol. Manage. 2010; 259:1786-1795.

6. Stoneman GL, Crombie DS, Whitford K, Hingston FJ, Giles R, Portlock CC, Galbraith JH, Dimmock GM. Growth and water relations of Eucalyptus marginata (Jarrah) stands in response to thinning and fertilization. Tree Physiol. 1996;17:267274.

7. La Sala AV. Pre-commercial thinning and fertilizer enhance growth in young native Eucalyptus obliqua (L'Herit.) stands in Tasmania. Aust. For. 2006;69:16-24.

8. Forrester DI, Elms S, Baker TG. Tree growth-competition relationships in thinned Eucalyptus plantations vary with stand structure and site quality. E. J. For. Res. 2013;132:241-252.

9. Blevins DP, Prescott CE, Allen $\mathrm{HL}$, Newsome TA. The effects of nutrition and density on growth, foliage biomass and growth efficiency of high-density fire-origin Lodgepole pine in central British Columbia. Can. J. For. Res. 2005;35:2851-2859.

10. Makinen $H$, Isomaki $A$. Thinning intensity and growth of Scots pine stands in Finland. For. Ecol. Manage. 2004;201:311-325.

11. Smethurst PJ. Forest fertilizer application: Trends in knowledge and practice compared to agriculture. Plant Soil 2010; 335:83-100.

12. Goncalves. Silvicultural effects on the productivity and wood quality of eucalypt plantations. For. Ecol. Manage. 2004; 193:45-61.

13. Goncalves JLM, Stape JL, Laclau JP, Bouillet JP, Ranger J. Assessing the 
effects of early silvicultural management on long-term site productivity of fastgrowing eucalypt plantations: The Brazilian experience. South For. 2008;70:105-118.

14. Evans J. Plantation Forestry in the Tropics. Clarendes Press, Oxford. 1992;250-255.

15. Koul VK, Bhardwaj SD, Kaushal AN. Effect of $\mathrm{N}$ and $\mathrm{P}$ application on nutrient uptake and biomass production in Bauhinia variegata Linn. Seedlings. Indian Forester. 1995;121:14-22.

16. Laman VK, Patil SK, Manjunath GO. Growth of Acacia auriculiformis as influenced by $\mathrm{N}, \mathrm{P}$ and $\mathrm{K}$ fertilizers. Kar. J. Agric. Sci. 2004;17:872-874.

17. Dang VT. Research on silviculture techniques for intensive plantation toward timber supply. Scientific report. Vietnamese Academy of Forest Sciences. Hanoi, Vietnam; 2010.

18. MARD. Biomass and carbon sink ability of some types of plantations in Vietnam.
Agricultural Publishing House. Hanoi, Vietnam; 2009.

19. Bennett LT, Weston CJ, Attiwill PM. Biomass, nutrient content and growth response to fertilizers of 6-year-old Eucalyptus globulus plantations at three contrasting sites in Gippsland. Aus. J. Botany. 1991;45:103-121.

20. Battaglia $M$, Sands $P$. Modelling site productivity of Eucalyptus globulus in response to climatic and site factors. Aus. J. Plant Physiol. 1997;24:831-850.

21. Tome M, Pereira JS. Growth and management of eucalypt plantations in Portugal. In: Ryan PJ. (eds.), Proceedings of the third Australian forest soils and nutrition conference on productivity in perspective. Forestry commission NSW, Sydney, Australia. 1981;147-157. Attiwill PM Energy, nutrient flow, and biomass. In: Australian forest nutrition workshop productivity in perpetuity. Melbourne, CSIRO Publishing, 1991;131-144.

(c) 2017 Do et al.; This is an Open Access article distributed under the terms of the Creative Commons Attribution License (http://creativecommons.org/licenses/by/4.0), which permits unrestricted use, distribution, and reproduction in any medium, provided the original work is properly cited.

Peer-review history:

The peer review history for this paper can be accessed here: http://sciencedomain.org/review-history/19255 